\title{
Preliminary research for eight possible groundwater energy utilisation sites in Southern Finland
}

Teppo Arola, Isa Witick, Joonas Kouvo, Jussi Kuusela

\begin{abstract}
Groundwater energy utilisation has not been widely regognised as a significant renewable energy source for industry in Finland. This investigation provides example of cost-effective study to map groundwater energy utilisation possibilities. The purpose of this investigation is to increase knowledge and promote groundwater energy utilisation in Finland. The investigation was carried out for eight industrial sites located on Nastola, Southern Finland. The research include geological site investigation with groundwater temperature measurements and existing geological, bydrological, geotechnical and environmental literature review. Based on investigations and sites energy consumption data site specific groundwater energy capacity was estimated. Possible environmental barriers for groundwater energy utilisation and preliminary economical calculation was also assessed. Groundwater pumping and infiltration demand for all sites is approximately $43.3 \mathrm{l} / \mathrm{s}$. No significant environmental issues was observed in this investigation. By utilising groundwater energy it is possible to save approximately 600000 to $800000 €$ in yearly energy costs. Hence groundwater energy utilisation can provide cost-effective renewable energy option to all sites. It is possible to plan common groundwater energy system for 2 to 3 companies and hence reduce investment costs. Further actions to continue site investigations is recommended to all sites.
\end{abstract}

\section{INTRODUCTION}

The consequences of climate change has forced international policy to focus increasingly to the energy sector development (Stehfest, et al. 2009; Valkila, et al. 2010). For example, the European Union has committed to reduce greenhouse gases from 85\% to 90\% below 1990 levels by 2050 (European Commission 2011). Special attention has been paid to the utilisation of renewable energy resources, such as geothermal energy. Geothermal energy utilisation can be divided to two main categories; a) deep geothermal energy which source is the earth's internal energy and systems normally operates in temperature regime of over $100{ }^{\circ} \mathrm{C}$ and b) shallow geothermal energy which source is mainly solar energy, which is absorbed by and stored to the upper part of the ground and system's operational temperature is much lower than in deep geothermal energy systems. In Nordic countries term geothermal is widely used to describe the deep geothermal systems and term geoenergy to describe shallow geothermal systems respectively. The term geoenergy is used in this artickle.

Geothermal energy utilisation for heating has increased in Europe (EGEC 2017). Due to technical, economical, climatological and geological reasons geoenergy utilisation is currently the most widely used geothermal resource in the Nordic countries, excluding Iceland. One option to produce geoenergy is to utilise groundwater reservoirs for

Teppo Arola (teppo.arola@gtk.fi) is a chief expert and Isa Witick is a researcher in the Geological Survey of Finland. Joonas Kouvo is a student and Jussi Kuusela is a project manager in the Lahti University of Applied Science. 
energy production. Groundwater has been widely used for decades as an energy resource, for instance in China (Banks 2009) and in North America (Ferguson and Woodbury 2005). In Europe, the Netherlands is currently leading groundwater energy producers, having over 2740 systems that utilise both heating and cooling energy from groundwater (Sommer 2014). Sweden has approximately 100 groundwater energy sites with a minimum capacity of $100 \mathrm{~kW}$ (Gehlin and Andersson 2016).

The groundwater energy utilisation (GEU) technique is called an open-loop energy system or open-loop system (Bonte, et al. 2011; Haehnlein, et al. 2010) where groundwater is pumped from extraction well, conveyed throught an energy-transfer system and returned the subsurface via an injection well. Short time energy storage can be added to the GEU system by designing the groundwater circulation to operate in two directions. This means that warm groundwater pumped from an extraction well in the winter is used for heating and hence returned to the injection well at a cooler temperature. In the summer the system is reversed with the purpose of the winter time injection well becomes an extraction well from where cooler groundwater is utilised for cooling purposes. This system is known as aquifer thermal energy storage (ATES) (Andersson 1998; Bonte, et al. 2011). Critical parameters to GEU are the amount of utilizable groundwater and its temperature. Suitable geological conditions, i.e. relatively high hydraulic conductivity are necessary to provide adequate groundwater flow. Urbanisation has significantly elevated groundwater temperatures under cities (Benz, et al. 2015; Memberg, et al. 2013), also in Finland (Arola and Korkka-Niemi 2014).

Even geological and climatological conditions in Finland are largely similar than in Sweden (Ehlers 1996) GEU systems are not widely used in Finland; only two industrial size ATES systems are in pilot phase. Hence, there is significant renewable energy reservoir (Arola, et al. 2014) which has not mobilized so far. This industrial related research report provides examples of cost-effective preliminary study to map GEU possibilities. The purpose of this investigation is to increase knowledge and promote GEU.

\section{MATERIAL AND METHODS}

The investigation was carried out for eight industrial sites located on Nastola, Southern Finland, approximately $100 \mathrm{~km}$ north-east from Helsinki (Fig.1). Geologically all sites are located on the Salpausselkä end-moraine complex (Fig. 2). Salpausselkä in Nastola is narrow east to west oriented ridge shape formation which topographically is approximately 20 to $30 \mathrm{~m}$ higher than surrounding landscape. The Centre for Economic Development, Transport and Environment (ELY) have categorized aquifers that are suitable for drinking water utilisation in Finland. These classified aquifers have legal status. All investigated sites are located inside classified aquifer in Nastola (Fig. 1 and 2). 


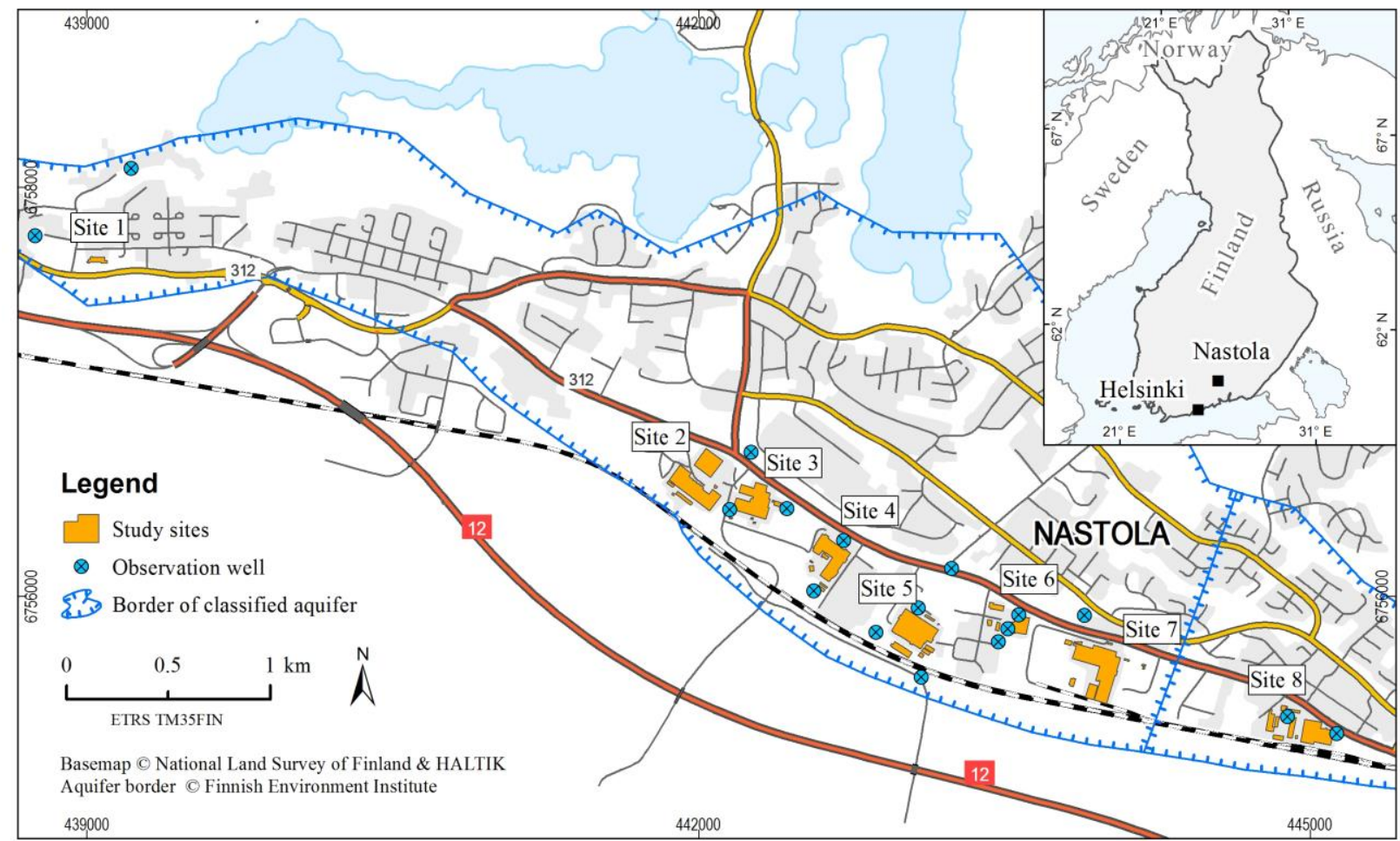

Figure 1 Location map including capital Helsinki (small map) and the study sites. The buildings in investigated property are highlighted with light brown colour. The border of classified aquifer and groundwater monitoring wells is also shown.

Site investigations. The work included literature review of existing geological, hydrological, geotechnical and environmental reports. Publically available information from the classified aquifer database and soil contamination database was investigated. A site visit to all locations were completed in June 2017. Site visit include interview of site manager, geological mapping and groundwater temperature measurements from existing groundwater wells.

Energy consumption data. Hourly based heating energy consumption data was available from seven sites and monthly based heating energy consumption data from one site. Hourly or monthly based cooling energy comsumption data was not available. The heating and cooling energy consumption varied significantly between sites; cooling energy is needed only in three sites. Cooling energy consumption was assessed based on the power demand of coolers and estimating the time needed for cooling. Several studies (i.e. Arola, et al. 2016; Holopainen, et al. 2010; Rosen, et al. 2001) has showed that economically the most suitable option is to dimension geoenergy heat pump system to cover $50 \%$ to $60 \%$ of the peak design heating power. Noticing above and the sites heating energy demand we calculate the scenarios where $30 \%$ and $60 \%$ of heating power and $100 \%$ of cooling power will be covered by GEU system. The results revealed which of the two scenarios would be more pragmatic both technically and environmentally and that scenario was selected for further estimations. 


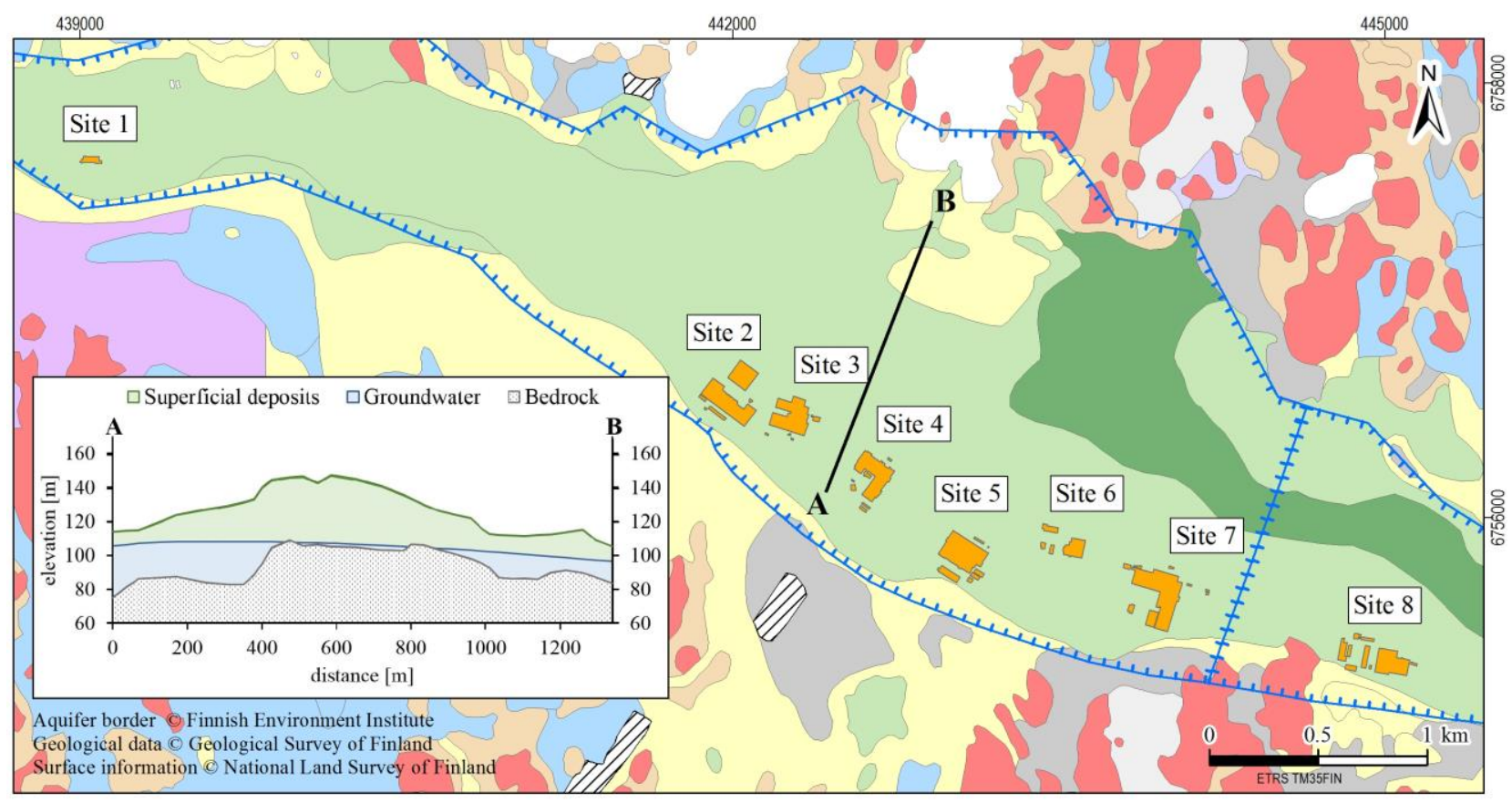

Legend

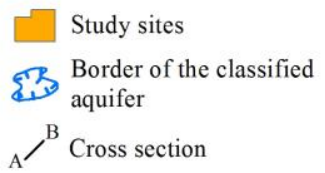

\section{Superficial deposits 1:20 000}

Bedrock, at or near surface
(less than $1 \mathrm{~m}$, generally till)
Sandy till, Gravelly till
Gravel

Figure 2 Superficial deposit map and cross section from the research area.

Groundwater pumping demand. The groundwater pumping requirements needed to achieve heating and cooling power were calculated on an hourly basis (8760 hours in a year) using the following equations (Allen, et al. 2003; Banks 2012):

Groundwater flux for heating: $F_{H}=H\left(1-\left(\frac{1}{C O P_{H}}\right)\right) /\left(\Delta T_{\text {in-out }} C_{w}\right)$

Groundwater flux for cooling: $F_{C}=C\left(1+\left(\frac{1}{C O P_{C}}\right)\right) /\left(\Delta T_{\text {in-out }} C_{w}\right)$

where $\mathrm{F}_{\mathrm{H}}=$ flux of water $\left(\mathrm{kgs}^{-1}\right)$ for heating and $\mathrm{F}_{\mathrm{C}}$ for cooling respectively, $\mathrm{H}$ is heating power $(\mathrm{W})$ and $\mathrm{C}$ cooling power $(\mathrm{W}), \Delta \mathrm{T}_{\text {in-out }}=$ temperature difference between incoming and outgoing water in the heat pump / heat exchanger $(\mathrm{K}), \mathrm{C}_{\mathrm{w}}=$ specific heat capacity of water $\left(\mathrm{J} \mathrm{kg}^{-1} \mathrm{~K}^{-1}\right), \mathrm{COP}_{\mathrm{H}}=$ coefficient of performance of the heat pump for heating (dimensionless), and $\mathrm{COP}_{\mathrm{C}}=$ coefficient of performance of the heat exchanger system for cooling (dimensionless). The groundwater flux unit $\mathrm{kgs}^{-1}$ was changed to $1 \mathrm{~s}^{-1}$ as the change has no real effects on the results and $1 \mathrm{~s}^{-1}$ is universally used to describe groundwater flow. In heating mode, groundwater utilisation down to a temperature of $+1{ }^{\circ} \mathrm{C}$ was assumed, and measured average groundwater temperature was used as $T_{\text {in }}$ value. Based on sites cooling system technique $16{ }^{\circ} \mathrm{C}$ or $22{ }^{\circ} \mathrm{C}$ was used as a groundwater returning temperature in cooling calculations. The specific heat capacities of water were taken from Yaws (1998). A heat pump was assumed to be used for heating and a heat exchanger for cooling applications. Based on the information presented by Allen et al. (2003), 
Bayer et al. (2011), Saner et al. (2010) and the European Heat Pump Association, EHPA (2009), a COP H $_{4}$ and $\mathrm{COP}_{\mathrm{C}}$ of 30 was used in this analysis.

Environmental effects. The area of groundwater depression cone was calculated by following equation (Fetter 2001):

$$
L_{\max }= \pm \frac{Q}{2 K b i}
$$

where $\mathrm{L}_{\max }$ is the theoretical maximum width of depression cone $(\mathrm{m}), \mathrm{Q}$ is the amount of pumped groundwater in day $\left(\mathrm{m}^{3} / \mathrm{d}\right), \mathrm{K}$ is the hydraulic conductivity of soil $(\mathrm{m} / \mathrm{d}), \mathrm{b}$ is the depth of aquifer $(\mathrm{m})$ and $\mathrm{i}$ is hydraulic gradient (dimensionless).

Site specific information of soil and groundwater contamination was gathered during the site visit by interviewing site managers.

Preliminary economical calculation. The unit costs of current heating and cooling power were gathered during site visits and yearly energy costs was calculated from each site. Preliminary energy savings was calculated in situation where current heating and cooling energy is replaced by GEU. The costs related to heat and water pump electricity was noticed in calculations.

\section{RESULTS}

Total groundwater pumping demand is approximately $1457081 \mathrm{~m}^{3}$ per year (table 1). Groundwater pumping demand varied significantly between sites due to differences in energy consumption. Average groundwater pumping demand, and injection demand in case of ATES, for all sites is approximately $4000 \mathrm{~m}^{3} / \mathrm{d}$ which corresponds to 43.3 $1 / \mathrm{s}$ and maximum daily pumping demand is approximately $7300-7400 \mathrm{~m}^{3}$. In property scale maximum groundwater pumping demand was $20 \mathrm{l} / \mathrm{s}$ and minimum $3 \mathrm{l} / \mathrm{s}$. The GEU experiment was estimated for office building only on site 8 due to technical and economic reasons. Hence, groundwater pumping demand is low on site 8 .

No glacial sediments or groundwater is known to be contaminated on the area of investigated properties. The width of groundwater depression cone was calculated to be between 40 to 500 metres (table 2). The depression cone was not estimated to reach the nearest communal groundwater intake well.

Groundwater temperature in non-urbanised area was observed to be $6.0{ }^{\circ} \mathrm{C}$, in traffic areas outside the industrial property between 6.6 to $7.1{ }^{\circ} \mathrm{C}$ and in industrial property near the buildings between 7.9 to $9.0{ }^{\circ} \mathrm{C}$ respectively.

Table 1. Groundwater pumping demands

\begin{tabular}{|c|c|c|c|c|c|c|}
\hline Site no: & $\begin{array}{c}\text { Yearly total } \\
\text { demand }\left(\mathbf{m}^{\mathbf{3}}\right)\end{array}$ & $\begin{array}{c}\text { Hourly avarage } \\
\left(\mathbf{m}^{\mathbf{3}} \mathbf{/} \mathbf{h}\right)\end{array}$ & $\begin{array}{c}\text { Daily average } \\
\left(\mathbf{m}^{\mathbf{3}} \mathbf{/ d}\right)\end{array}$ & Max. $(\mathbf{l} / \mathbf{s})$ & Max. $(\mathbf{m} 3 / \mathbf{h})$ & Max. $(\mathbf{m} 3 / \mathbf{d})$ \\
\hline 1 & 55082 & 7.36 & 177 & 3.1 & 11.1 & 246 \\
2 & 255932 & 29.2 & 701 & 11.3 & 40.6 & 973 \\
3 & 317837 & 36.3 & 871 & 19.8 & 71.3 & 1712 \\
4 & 353255 & 40.3 & 968 & 15 & 54 & 1302 \\
5 & 300084 & 34 & 820 & 16 & 56 & 1355 \\
6 & 35906 & 4 & 98 & 3 & 11 & 271 \\
7 & 105737 & 12.1 & 290 & 13.7 & 49.4 & 1184 \\
8 & 33248 & 4 & 91 & 4 & 15 & 308 \\
\hline Total & 1457081 & 4016 & & \\
\hline
\end{tabular}




\section{Table 2. Calculated widht of groundwater depression cone and site distance to the nearest communal water intake station}

\begin{tabular}{|c|c|c|}
\hline Site & Widht $(\mathbf{m})$ & $\begin{array}{c}\text { Distance to the nearest } \\
\text { water intake well }(\mathbf{m})\end{array}$ \\
\hline 1 & 40 & 700 \\
2 & 200 & 1300 \\
3 & 300 & 1200 \\
4 & 400 & 1300 \\
5 & 500 & 1500 \\
6 & 70 & 1600 \\
7 & 150 & 1600 \\
8 & 100 & 2000 \\
\hline
\end{tabular}

Economical calculation revealed that it is possible to save approximately 600000 to $800000 €$ in yearly energy costs by utilising groundwater energy in every site.

\section{DISCUSSION}

The groundwater pumping demand for each site is realistic and achievable. The ELY-centre has estimated that total recharge of the aquifer in question is $7800 \mathrm{~m}^{3} / \mathrm{d}$. Permissions for current groundwater intake wells situated in aquifer allows groundwater pumping of $9800 \mathrm{~m}^{3} / \mathrm{d}$. In principle ATES system does not affect to the total groundwater balance as same amount of groundwater is injected back to the aquifer as has been pumped out. However, it can be estimated that in Salpauselkä environment $100 \%$ groundwater injection may not be possible. Salpausselkä is heterogeneous and contains several different grain size units which is known to create semi-confined aquifer conditions.

Urbanisation and industrial activity has arisen groundwater temperature 1 to $3{ }^{\circ} \mathrm{C}$ from its natural temperature. Observed temperatures are within same limit as measured before from industrial areas in Finland (Arola and KorkkaNiemi 2014). Due to elevated groundwater temperature less groundwater is needed to pump to achieve targeted heating power. One degree increase in groundwater temperature results approximately $20 \%$ decrease in groundwater pumping demand if the pumping amount is $4016 \mathrm{~m}^{3} / \mathrm{d}$. Hence urbanisation has significant positive effect to groundwater heating utilisation, both economic and environmentally. Similarly it has negative impact to cooling energy utilisation. However, groundwater temperature is still low even in industrial areas and hence will provide costeffective solution to cooling also.

Although no soil or groundwater chemical contamination is known it is possible that soil and groundwater is contaminated on the research area. This is due to several decades of industrial activity. Hence industrial activity was in place in Nastola before environmental legislation in Finland. Groundwater pumping and injecting can accelerate groundwater contaminants movement and hence it is essential to know possible contaminant sources in GEU. In general, groundwater quality is suitable for low-temperature groundwater energy utilisation and storage in Finland. However, high $\mathrm{Fe}$ and $\mathrm{Mn}$ concentrations exist in confined aquifers, where clay deposits overlay sand or gravel units creating unoxic environment (Korkka-Niemi, 2001). Similar unoxic environment is also possible to exist in Salpausselkä region. Hatva (1989) reported maximum Fe concentrations of 27 to $37.4 \mathrm{mg} / \mathrm{l}$ and Mn concentrations of 1.9 to $2.3 \mathrm{mg} / \mathrm{l}$ in aquifers where clays overlay coarse-grained soil material. These circumstances may cause technical obstacles to GEU system functioning.

Economically yearly savings in GEU system are significant compared to modern heating and cooling costs. 
However, this preliminary research concentrates only for thermogeological aspects and engineering changes to energy utilisation, such as piping, drilling, heat pumps etc. is not covered meaning that investment costs are not known at the moment. Banks (2009) and Arola et al. (2016) showed that ATES system increased groundwater energy potential compared to heating or cooling energy utilisation only. The investment costs are more critical on the sites where no current cooling system exists. In these sites it might be more cost-effective to plan simply groundwater heat pump (GWHP) system instead of ATES even cooling energy production from groundwater is extremely cost effective.

Sites 2,3,4,5, and 6 and 7 are locating on neighbour properties. Hence it is possible to plan common ATES systems for example 2 to 3 sites where all sites would utilise same pumping and injection wells. This solution would decrease investment costs. However, common ATES system for 2 or 3 sites will need significant planning for operating phase due to heterogeneous energy consumption between the sites. The geological media, sand and gravel, and groundwater temperature regime is similar than reported from Swedish and Norwegian ATES sites (Andersson, 1998; Eggen and Vangnes, 2005).

\section{CONCLUSION}

Groundwater energy utilisation in all research sites is thermogeologically possible and can provide cost-effective solution for heating and cooling energy utilisation. It is also possible to plan common ATES systems where 2 or 3 sites will pump and inject groundwater from common wells. Utilising ground for heating in urbanised area is partly reuse of former waste energy.

Further HPAC, geotechnical and groundwater investigation has been recommended to all sites. Further investigations will provide more accurate information for feasibility study which is needed for decision makers.

This study provided necessary thermogeological information to companies to plan the next steps in GEU process. Investigation showed that thermogeological resource estimation in the first phase of GEU process is essential but can be done in very cost-effective way without massive in situ investigations and tests.

\section{ACKNOWLEDGMENTS} your sites.

We want to thank all the companies and the Nastolan Energiasäätiö for the opportunity to provide research on

\section{NOMENCLATURE}

ATES $=$ aquifer thermal energy storage

GEU $=$ groundwater energy utilisation

HPAC = heating, plumbing, air-conditioning

$\mathrm{F}_{\mathrm{H}}=$ flux of water for heating $\left(\mathrm{kgs}^{-1}\right)$

$\mathrm{F}_{\mathrm{C}}=$ flux of water for cooling $\left(\mathrm{kgs}^{-1}\right)$

$\mathrm{H}=$ heating power $(\mathrm{W})$

$\mathrm{C}=$ cooling power $(\mathrm{W})$

$\mathrm{T}=$ groundwater temperature $(\mathrm{K})$

$\mathrm{C}_{\mathrm{w}}=$ specific heat capacity of water $\left(\mathrm{kgg}^{-1} \mathrm{~K}^{-1}\right)$

$\mathrm{COP}_{\mathrm{H}}=$ coefficient of performance of the heat pump for heating (dimensionless)

$\mathrm{COP}_{\mathrm{C}}=$ coefficient of performance of the heat exchanger system for cooling (dimensionless)

$\mathrm{L}_{\max }=$ theoretical maximum width of groundwater pumping depression cone $(\mathrm{m})$

$\mathrm{Q}=$ the amount of pumped groundwater in day $\left(\mathrm{m}^{3} / \mathrm{d}\right)$

$\mathrm{K}=$ the hydraulic conductivity of soil $(\mathrm{m} / \mathrm{d})$

$\mathrm{b}=$ the depth of aquifer $(\mathrm{m})$

$\mathrm{i}=$ the hydraulic gradient (dimensioless). 


\section{REFERENCES}

Allen, A. Milenic, D and Sikora, P. 2003. Shallow gravel aquifersand urban 'heat island'effect: a source of low entalphy geothermal energy. Geothermics 32:569-578. doi:10.1016/S0375-6505(03)00063-4.

Andersson, O. 1998. Heat pump supported ATES applications in Sweden. IEA Heat Pump Centre Newsletter 16:20-21.

Arola T. Okkonen J and Jokisalo J. 2016. Groundwater utilisation for energy production in the Nordic environment: an energy simulation and bydrogeological modelling approach. Journal of Water Resource and Protection 8, 642-656. doi: org/10.4236/jwarp.2016.86053.

Arola, T and Korkka-Niemi, K. 2014. The effect of urban heat islands on geothermal potential: examples from Quaternary aquifers in Finland. Hydrogeology Journal 22, 1953-1967. doi: 10.1007/s10040-014-1174-5.

Arola T. Eskola L. Hellen J and Korkka-Niemi K. 2014. Mapping the low entalphy geothermal potential of shallow Quaternary aquifers in Finland. Geothermal Energy 2:9. doi:10.1186/s40517-014-0009-x.

Banks, D. 2012. An introduction to thermogeology. Ground source heating and cooling. Wiley -Blackwell Publishing. Oxford England.

Banks, D. 2009. Thermogeological assessment of open-loop well-doublet schemes: a review and synthesis of analytical approaches. Hydrogeology Journal 17:1149-1155. doi: 10.1007/s10040-008-0427-6.

Bayer, P., Saner, D., Bolay, S., Rybach, L and Blum, P. 2011. Greenhouse gas emission savings of ground source beat pump systems in Europe: A review. Renew Sust Energ Rev, 16, 1256 - 1267. doi 10.1016/j.rser.2011.09.027.

Benz, SA., Bayer, P., Menberg, K., Jung, S and Blum, P. 2015. Spatial resolution of anthropogenic heat fluxes into urban aquifers. Science of the Total Environment 524-525: 427-439.

Bonte, M., Stuyfzand, P., Hulsmann, A and van Beelen, P. 2011. Underground thermal energy storage: Environmental risks and policy developments in the Netherlands and European Union. Ecology and Society 16(1):22.

EGEC. 2017. 2016 EGEC geothermal market report. European geothermal energy counsil. Brussels.

Eggen, G and Vangsnes, G. 2005. Heat Pump for district cooling and heating at Oslo airport, Gardemoen. In proceedings of the 8th IEA Heat Pump Conference. Las Vegas, Nevada, USA May 30 - June 22005.

EHPA. 2009. European heat pump statistic - Outlook. 2009. European Heat Pump Association. pp. 65. Brussels.

Ehlers, J. 1996. Quartenary and Glacial Geology. John Wiley \& Sons

European Commission. 2011. Energy roadmap 2050. European Commission. Brussels.

Ferguson, G and Woodbury, AD. 2005. Thermal sustainability of groundwater-source cooling in Winnipeg, Manitoba. Canadian Geotechnical Journal 42: 1290-1301. doi: 10.1139/T05-057.

Fetter, CW. 2001. Applied Hydrogeology. $4^{\text {rd }}$ edition. Prentice-Hall inc. USA.

Gehlin, S and Andersson, O. 2016. Geothermal Energy Use, Country Update for Sweden. European Geothermal Congress 2016.

Haehnlein, S., Bayer, P and Blum, P. 2010. International legal status of the use of shallow geothermal energy. Renewable and Sustainable Energy Review 14: 2611-2625. doi: 10.1016/j.rser.2010.07.069.

Hatva, T. 1989. Iron and manganese in groundwater in Finland. Occurrence in glaciofluvial aquifers and removal by biofiltration. National Board of Waters and the Environment. Helsinki. Finland.

Holopainen, R., Vares, S., Ritola, J and Pulakka, S. 2010. Maalämmön ja viilennyksen byödyntäminen asuinkerrostalon lämmityksessä ja jäähdytyksessä. VTT - Research notes 2546. 56 pp. Espoo Finland.

Korkka-Niemi, K. 2001. Cumulative geological, regional and site-specific factors affecting groundwater quality in domestic wells in Finland. Monograph of the Boreal Environment Research vol. 20. 102 pp.

Menberg, K., Bayer, P., Zosseder, K., Rumohr, S and Blum, P. 2013. Subsurface urban beat islands in German cities. Science of the Total Environment 442: 123-133. doi: 10.1016/j.scitotenv.2012.10.043.

Rosen, B., Gabrielsson. A., Fallsvik. J., Hellström, G and Nilsson, G. 2001. System för värme och kyla ur mark - En nulägesbeskrivning. Varia 511. Statens Geotekniska Institut, Lindköping, Sweden.

Saner, D., Juraske, R., Kübert, M., Blum, P., Helweg, S and Bayer, P. 2010. Is it only CO2 that matters? A life cycle per-spective on shallow geothermal system. Renew Sust Energ Rev, 14, 1798-1813. doi: 10.1016/j.rser.2010.04.002.

Sommer, W. 2014. Large scale application of Aquifer Thermal Energy Storage, in 5th European Geothermal PhD Day. Abstracts, pp. 79-81. Technical University of Darmstadt, Germany.

Stephfest, E., Bouwman, L., van Vuuren, DP., den Elzen, MGJ and Eichout, B. 2009. Climate benefits of changing diet. Climatic Change 95: 83-102. 
Valkila, N and Saari, A. 2010. Urgent need for new approach to energy policy: the case of Finland. Renewable\&Sustainable Energy Reviews: 14: 2068-76.

Yaws, C. 1998. Chemical properties handbook: physical thermodynamic, environmental, transport, safety and health related properties for organic and inorganic chemicals. McGraw-Hill: New York. 